University of Nebraska - Lincoln

DigitalCommons@University of Nebraska - Lincoln

8-2002

\title{
Re-test of Rhinocyllus conicus host specificity, and the prediction of ecological risk in biological control
}

Amy E. Arnett

Unity College, aarnett@unity.unity.edu

Svata M. Louda

University of Nebraska - Lincoln, slouda1@unl.edu

Follow this and additional works at: https://digitalcommons.unl.edu/bioscifacpub

Part of the Life Sciences Commons

Arnett, Amy E. and Louda, Svata M., "Re-test of Rhinocyllus conicus host specificity, and the prediction of ecological risk in biological control" (2002). Faculty Publications in the Biological Sciences. 88.

https://digitalcommons.unl.edu/bioscifacpub/88

This Article is brought to you for free and open access by the Papers in the Biological Sciences at DigitalCommons@University of Nebraska - Lincoln. It has been accepted for inclusion in Faculty Publications in the Biological Sciences by an authorized administrator of DigitalCommons@University of Nebraska - Lincoln. 
Published in Biological Conservation 106:2 (August 2002), pp. 251-257; doi: 10.1016/S0006-3207(01)00251-8

Copyright (C) 2002 Elsevier Science Ltd. Used by permission. http://www.elsevier.com/locate/biocon

Submitted April 23, 2001; accepted October 12, 2001; published online November 27, 2001.

\title{
Re-test of Rhinocyllus conicus host specificity, and the prediction of ecological risk in biological control
}

\author{
Amy E. Arnett and Svata M. Louda \\ School of Biological Sciences, University of Nebraska, Lincoln, NE 68588, USA \\ Corresponding author - A. E. Arnett; present address: Department of Environmental Programs, \\ Unity College, Unity, ME 04988, USA; email aarnett@unity.unity.edu
}

\begin{abstract}
Biological control is proposed as an ecological strategy to manage the threat of invasive plants, especially in natural areas. To pursue this strategy, we need to know that the host specificity criteria used to evaluate ecological risk with deliberate introduction of an exotic insect for biocontrol are sufficient to predict potential impact on native species. Host specificity is defined by adult feeding and oviposition preferences and larval development. One way to evaluate the criteria is to re-examine case histories where ecological effects are recorded, such as that of Rhinocyllus conicus Frölich. This flower head weevil, released in North America in 1968 to control exotic thistles like Musk thistle (Carduus nutans L), is now reducing seed production by multiple native North American thistle species (Cirsium spp.), and local population density of Platte thistle (Cirsium canescens Nutt.). We hypothesized that host specificity of $R$. con$i c u s$ has changed since pre-release testing, providing an explanation for the unexpected magnitude of the documented ecological effects. Instead, when we re-tested host specificity of weevils naturalized over 28 generations, we found that host specificity has not changed. Naturalized adults of $R$. conicus showed strong feeding and oviposition preference for Musk thistle over Platte thistle. In addition, larval development by these weevils was faster and more successful (to larger size) on Musk thistle than on Platte thistle. Thus, our results indicate that a change in host specificity cannot explain the unexpectedly large build-up of $R$. conicus and significant ecological effect on Platte thistle. We conclude that accurate prediction of the potential level of impact on native host plants in the field requires further ecological information in addition to host specificity.
\end{abstract}

Keywords: biological control of weeds, nontarget effects, thistles, Cirsium, inflorescence feeding, Rhinocyllus, Curculionidae, weed biocontrol, ecological risk

\section{Introduction}

The threat to natural ecosystems posed by invasive plant species makes control and management of exotic weeds a pressing contemporary issue in conservation biology (Office of Technology Assessment, 1993; Randall, 1996; Wilcove et al., 1998; Pimentel et al., 2000). As awareness of the invasives problem has grown, an increased emphasis has been placed on developing biological controls (Delfosse, 2000). Classical biological control involves the discovery, evaluation, and release of natural enemies of an invasive species from its area of origin in an attempt to suppress the abundance of the pest species in its area of invasion (Murdoch et al., 1985; Debach and Rosen, 1991 ; Van Driesch and Bellows, 1993; Thomas and Willis, 1998; Strong and Pemberton, 2000).

The argument has been made specifically that biolog- ical control of weeds should be used in limiting weedy plants in natural areas (e.g. Malecki and Blossey, 1994). The typical justification for such recommendations is that biological control represents an ecological, environmentally sound, sustainable, and cost-effective management strategy for invasive weed management (e.g. Malecki and Blossey, 1994; MacFadyen, 1998). However, the deliberate importation and release of any exotic organism entails an ecological risk to native species (Simberloff, 1986, 1992; Howarth, 1991; Simberloff and Stiling, 1996; Stiling and Simberloff, 2000). Recent case histories document non-target ecological effects (e.g. Louda et al., 1997, 1998; Johnson and Stiling, 1998; Boettner et al., 2000; Follett and Duan, 2000; Stiling and Simberloff, 2000; Louda and Arnett, 2000; Wajnberg et al., 2001). These reports provide added incentive to re-examine the criteria used to evaluate ecological risk. 
Insect host specificity, defined as adult preference and larval performance, is used to predict post-release host range and infer ecological risk (Harris and McEvoy, 1985; McEvoy, 1996; MacFadyen, 1998; Marohasy, 1998; Thomas and Willis, 1998; Strong and Pemberton, 2000). For example, if any host plant feeding by adult insects occurs, "It is traditional in host tests to equate vulnerability with suitability for larval development" (McEvoy, 1996). An underlying assumption implicit in this use of host specificity tests is that adult preference and larval performance are sufficient to predict not only which hosts are likely to be used, but also to indicate the relative amount of use secondarily acceptable (non-preferred) native host plants are likely to experience (e.g. Zwölfer and Harris, 1984; McClay, 1990; Blossey et al., 1994).

Host specificity, however, may not always predict the intensity of insect-plant interactions under field conditions. For example Larinus planus L., an exotic weevil which began to be distributed into the western US for control of the exotic Canada thistle (Cirsium arvense) in 1991, is now impacting a native thistle in Colorado (Louda and O'Brien, 2001). Redistribution of $L$. planus into the west from the east, where it is adventive, has occurred after host specificity tests were done by McClay (1990) using contemporary methods (Louda and O'Brien, 2001). McClay (1990) found evidence of adult preference for Canada thistle, and better larval performance by L. planus on it than on the native North American Cirsium spp. he tested. These host specificity results were used, as is usual, to conclude that only "occasional feeding and oviposition" would occur on native species (McClay, 1990). However, the field data now contradict this conclusion, since L. planus significantly reduces seed production of the native Tracy's thistle [Cirsium undulatum (Nutt.) Spreng. var. tracyi (Rydb.) Welsh], near L. planus release sites in Colorado (Louda and O'Brien, 2001). Surprisingly, the amount of seed destruction in 2000 was greater on the largeheaded native thistle than on the targeted small-headed Canada thistle (Louda and O'Brien, 2001). Unexpected nontarget effects also have been reported recently in insect biological control (e.g. Obrycki et al., 1998; Follett and Duan, 2000; Boettner et al., 2000; Wajnberg et al., 2001), as well as weed biological control (Johnson and Stiling, 1998; see also Pemberton, 2000). Such evidence suggests that the assumption that preference and performance (host specificity) indicate, not only host range, but also the relative vulnerability of related native host species under field conditions needs to be further evaluated.

One approach for such an evaluation is to re-examine cases with documented non-target ecological impacts, and to ask if host specificity has changed since pre-release testing. If so, the unexpected ecological effects could be explained by the change. If not, the results would imply that additional data were needed to predict the impact observed in the field. In this study, we re-evaluated the preference and performance of Rhinocyllus conicus, a weevil released to control exotic thistles but recently discovered to be exerting significant ecological pressure on a subset of native North American thistles (Louda et al., 1997, 1998; Louda, 1998, 2000; Louda and Arnett, 2000). Specifically, we tested the host specificity of weevils naturalized in North America for over 28 generations to determine if the adult preference or larval performance have shifted since pre-release and early post-release testing. We hypothesized that host specificity has changed, helping to explain the field results. The null hypothesis is that host specificity has not changed, suggesting further data are needed to predict the field results.

\subsection{Rhinocyllus conicus}

Host specificity of $R$. conicus was evaluated originally in both the laboratory prior to release and the field soon after release in North America. The pre-release data were initially available only in unpublished reports (Zwölfer, 1964, 1967, 1969). The data in the pre-release reports and in early post-release studies were synthesized and finally published by Zwölfer and Harris, (1984). Thus, the latter publication represents the best published source of information on the host specificity of $R$. conicus.

First, field data from Europe showed that $R$. conicus host use was restricted to true thistles (Carduinae), including multiple European Carduus spp., Cirsium spp., and Silybum marianum.

Second, the preference tests in Europe showed adult $R$. conicus only marginally accepted most of the Cirsium spp. tested for feeding or oviposition, which included one North American species, wavyleaf thistle (C. undulatum (Nutt.) Spreng.). Overall, the evidence suggested that $R$. conicus adults strongly preferred Carduus nutans over the Cirsium spp. tested (Zwölfer and Harris, 1984). After release in North America, the weevils from Europe also exhibited a preference in the field for Carduus nutans over Cirsium spp. thistles. For example, Rees (1977, 1978) found R. conicus in Montana had oviposited on 98$99 \%$ of the exotic C. nutans, versus on $22-41 \%$ of the cooccurring native wavyleaf thistle, C. undulatum.

Third, larval performance on $C$. nutans was better than that on the Cirsium spp. tested. For example in a small-scale post-release Canadian test, larval mortality was 20 times higher, larval size was "smaller," and new adult body mass was $5.8 \%$ lower for $R$. conicus on a native thistle, Cirsium flodmanii (Rydb.) Arthur, than it was on the exotic weedy thistle, C. nutans (Zwölfer and Harris, 1984). Based on such results from the host specificity testing, Zwölfer and Harris (1984) predicted that stronger oviposition preference for $C$. nutans and greater lar- 
val performance on it would preclude significant ecological effects on North American Cirsium spp. They stated (p. 59) that it was: "unlikely that the native thistles will be adopted as a prime host."

Fourth, in spite of this evidence of preference for and better performance on $C$. nutans, $R$. conicus now uses about a third of the species of native North American Cirsium thistles examined (Goeden and Ricker, 1986a, 1986b, 1987a, 1987b; Turner et al., 1987; Palmisano and Fox, 1995; Herr, 2000), and frequency of use appears to be increasing in preserves and national parks of the Great Plains and Rocky Mountains (Louda et al., 1997, 1998; Louda, 1998, 2000). Furthermore, where experimental and long-term data on thistle-insect interactions were available, the evidence also suggested that the increase in R. conicus has had significant direct and indirect ecological consequences (Louda et al., 1997, 1998; Louda, 1998, 2000; Louda and Arnett, 2000). For Platte thistle (Cirsium canescens Nutt.), production of viable seeds per plant decreased significantly (Louda et al., 1997, 1998), plant density in demography plots declined dramatically (Louda and Arnett, 2000), and populations of a floral-feeding native fly (Paracantha culta Weid. [Tephritidae]) appear to have been impacted negatively (Louda et al., 1997, 1998; Louda and Arnett, 2000). Thus, this case history provides an exceptional opportunity to re-examine host specificity and to ask if it has changed enough to explain the magnitude of these documented ecological effects.

\section{Methods}

To evaluate the effectiveness of the preference and performance components of host specificity in this case, we repeated the original tests using $R$. conicus naturalized in Nebraska. The first experiment was designed to be similar to the original laboratory screening tests (Zwölfer and Harris, 1984) to determine oviposition preference of $R$. conicus between the exotic Musk thistle, C. nutans L. subsp. leiophyllous (Petr.) Stoj. and Stef., naturalized in Nebraska (USDA, Natural Resource Conservation Service, 1999) and the heavily-impacted native Platte thistle, C. canescens Nutt. (Louda et al., 1997; Louda and Arnett, 2000). In this test we quantified egg load in laboratory tests of oviposition choice. The second experiment was designed to parallel the garden experiments done in the biological control program to assess larval development (Zwölfer and Harris, 1984). In this test, we quantified larval survival and development of naturalized $R$. conicus on both naturalized Musk thistle and on native Platte thistle under field conditions.

For the first experiment to evaluate oviposition preference, we collected adult $R$. conicus in early June 1998 in western Nebraska from both Musk thistle (Lincoln
County, $n=30$ mating pairs) and Platte thistle (Arthur County, $80 \mathrm{~km}$ northwest of Lincoln County site; $n=30$ mating pairs). In the laboratory at the University of Nebraska Cedar Point Biological Station in Ogallala Nebraska, flasks containing one branch of Platte thistle and one of Musk thistle in hydroponic solution were placed inside each of 32 insect rearing cages $(30 \times 30 \times 30 \mathrm{~cm}$; $0.5 \mathrm{~mm}$ mesh). The branches were matched by the number and size of flower heads. Two mating pairs of $R$. conicus adults collected from a host plant species were placed into each cage $(n=16$ replicates for weevils from each host plant species).

The number of eggs laid on each head was recorded in the morning, afternoon, and evening for 5 days. We used the number of eggs on the morning of the third day to quantify oviposition preference because most of the weevils (90\%) had laid eggs by the end of the second day and because egg cases began dropping off by the fourth day. The response variable, number of eggs laid per head, was analyzed with a two-way ANCOVA. Although heads were paired initially by size (diameter) within each replicate, flower head diameter was transformed $\left(\log _{10}\right)$ to normalize the data and used as a covariate since egg deposition could vary with flower head size differences among replicates. The contrasts in egg deposition analyzed were: host plant species in the field (Musk or Platte thistle) vs. host plant species observed for oviposition in the lab (Musk or Platte thistle).

For the second experiment to assess larval performance in the field, we collected adult $R$. conicus in midMay 1998 from two Musk thistle populations (Lincoln County, $8 \mathrm{~km}$ apart) and two Platte thistle populations (Arthur County, $8 \mathrm{~km}$ apart). These areas were chosen to be as close as possible $(80 \mathrm{~km})$ since these thistles do not occur in the same microhabitat. In early May, fine mesh enclosure bags were placed over a subset of uninfested flowerheads at one site for each species $(n=200 /$ site) to protect flower heads from insect feeding prior to experimental treatment. Mating pairs of weevils were collected in mid-May ( $n$ = pairs): musk site 1, $n=408$; musk site 2, $n=42$; Platte site 1, $n=238$; Platte site 2, $n=$ 98. We randomly assigned two mating pairs of weevils from a single host population to a flower head within a site. Weevils were placed onto the flower heads within the enclosure bags at both the main Musk site and at the main Platte site. Adult weevils were removed from the bags after 5 days or after they had laid at least four eggs, a low density (Louda, 1998; unpublished data). In addition, egg density was standardized to flower head diameter; so, larger heads were allowed to receive more eggs, to create equal density per unit volume of flower head. Excess eggs were scraped off the head. The bags were kept over the heads until either the larvae were sampled or the adult weevils that developed from the eggs were collected. 
To quantify larval development, we randomly chose flower heads at each main site after 6 weeks, and dissected them. Live larvae were weighed to $0.01 \mathrm{mg}$ (Platte, $n=22$ heads, 28 larvae; musk, $n=23$ heads, 42 larvae). The remaining flower heads were collected in early August as weevils matured, returned to the laboratory, and dissected. Adult progeny were removed, counted, dried in a drying oven for $24 \mathrm{~h}$ at $97^{\circ} \mathrm{C}$, and weighed to the 0.01 mg (musk source/musk host: $n=76$; Platte source/musk host: $n=69$; musk source/Platte host: $n=146$; Platte source/Platte host: $n=98$ ). The effect of the source thistle species from which the weevils were collected (musk or Platte) and the effect of the host thistle species on which the weevils were raised (musk or Platte) were the two treatments in the ANCOVA. Transformed $\left(\log _{10}\right)$ flowerhead diameter $(\mathrm{mm})$ was used as the covariate. Transformed $\left(\log _{10}\right)$ body masses of larvae and of the newly developed adult progeny were the two response variables.

\section{Results}

In the first experiment, oviposition rates by naturalized $R$. conicus were significantly greater on naturalized Musk thistle (C. nutans) than on native Platte thistle (C. canescens; Figure 1), consistent with the original tests (Zwölfer and Harris, 1984). Weevils laid eggs on the exotic Musk thistle in $93 \%$ of the cages, but on the native Platte thistle in only $68 \%$ of the cages. Significantly greater numbers of eggs were laid on Musk thistle than on Platte thistle $(P<$ 0.001, Figure 1). Flowerhead diameter was a significant

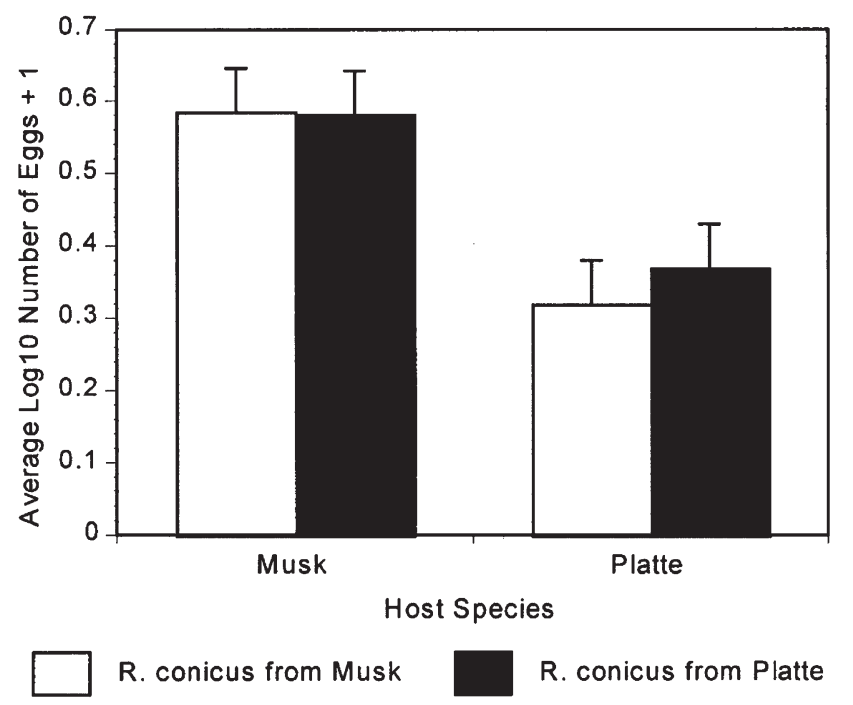

Figure 1. Average number of eggs ( \pm 1 S.D.) laid by naturalized Rhinocyllus conicus weevils on the native Platte thistle (Cirsium canescens) versus on the naturalized exotic musk thistle (Carduus nutans subsp. leiophyllous) in our laboratory oviposition-choice experiment. Significantly more eggs were laid on musk thistle than on Platte thistle $\left(\mathrm{F}_{1,156=14.02, P<0.001)}\right.$. Statistics are based on $\log _{10}$-transformed data. covariate $\left(F_{1,156}=4.07, P=0.046\right)$ as expected, but the host plant from which the weevils were collected in the field did not have an effect $\left(F_{1,156}=0.54, P=0.46\right)$. The strongest effect in the statistical analysis of this laboratory test was host plant oviposition choice (Figure 1). These results parallel those reported for the early post-release assessment in Montana: more Carduus plants than C. undulatum plants had eggs (Rees, 1977, 1978), and more eggs were laid on C. nutans than on the Cirsium spp. thistles present (Zwölfer and Harris, 1984).

In the second experiment, larval development measured as larval mass at 6 weeks was significantly greater on the naturalized exotic thistle than on the new native host thistle (Figure $2 \mathrm{a}, F_{1,63}=5.75, P=0.02$ ). These results parallel those summarized by Zwölfer and Harris
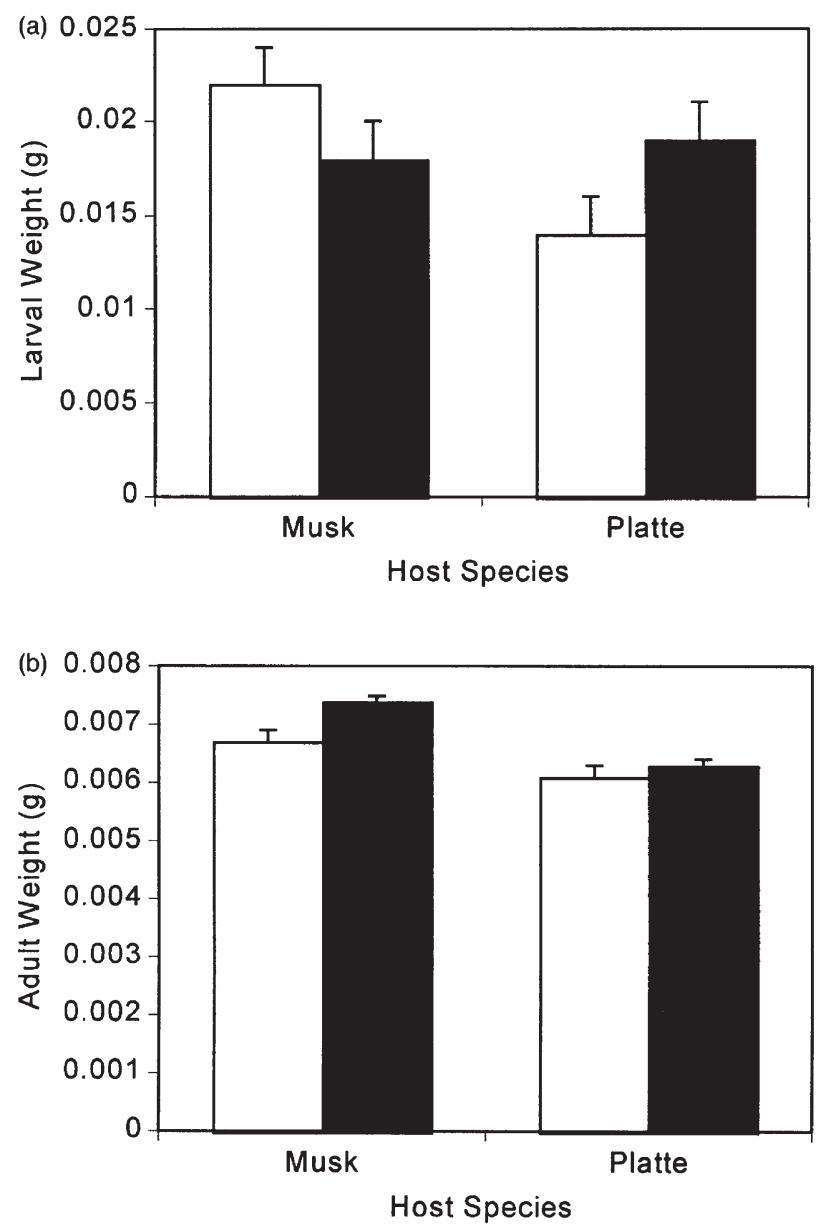

R. conicus from Musk

R. conicus from Platte

Figure 2. (a) The average mass ( \pm 1 S.D.) of larvae of naturalized Rhinocyllus conicus raised on naturalized musk thistle (Carduus nutans subsp. leiophyllous) was significantly greater than that of larvae raised on the newly adopted native host, Platte thistle (Cirsium canescens) $\left(\mathrm{F}_{1,63}=5.51, P=0.02\right)$; and $(\mathrm{b})$ the average mass of adult weevils raised on musk thistle and those raised on Platte thistle was not significantly different $\left(\mathrm{F}_{1,55}=0.07, P=\right.$ $0.07)$, although there was a tendency toward being greater for weevils emerging from musk thistle than from Platte thistle. Statistics are based on $\log _{10}$-transformed data. 
(1984) for the early studies. The thistle species from which a weevil was collected $\left(F_{1,63}=5.90, P=0.02\right)$, as well as the covariate flowerhead diameter $\left(F_{1,63}=22.43\right.$, $P<0.001)$, helped explain the variation in larval mass observed (Figure 2a). Larvae developing from eggs laid by weevils from Musk thistle did not grow as well on Platte thistle as did larvae developing from eggs laid by weevils from Platte thistle.

However, larval performance measured as final adult size (mass) did not differ significantly between host plant species. None of the effects were significant in the full model (Figure 2b; thistle species on which weevil was raised: $F_{1,55}=3.22, P=0.07$; thistle species from which parental weevil was collected: $F_{1,55}=1.84$, $P=0.18$; flowerhead diameter: $\left.F_{1,55}=0.71, P=0.40\right)$. Although we found no significant difference in adult mass between weevils that developed on Musk thistle versus on Platte thistle $(P=0.07$, Figure $2 b)$, the trend observed was toward larger individuals on Musk thistle and this was consistent with the original observations (Zwölfer and Harris, 1984).

\section{Discussion}

Our results eliminate the hypothesis that host specificity, measured as adult preference and larval performance, changed significantly between the pre-release studies and the occurrence of major post-release nontarget ecological effects on Platte thistle in Nebraska. Instead, our results suggest that the host specificity criteria predicted the acceptance, but not the magnitude of feeding observed on this native species. In spite of stronger preference for (Figure 1) and higher performance on (Figure 2a) Musk thistle, oviposition and development by naturalized $R$. conicus on Platte thistle has reduced the seed production (Louda et al., 1997) and plant density in demography plots has dropped dramatically (Louda and Arnett, 2000).

One potential reason for the discrepancy between the expectation of only limited impact based on host specificity tests (Zwölfer and Harris, 1984) and the ecological effects actually observed in Nebraska is that the preferred host plant (C. nutans) does not co-occur with Platte thistle (C. canescens) within Sand Hills prairie in Nebraska (personal observation). Thus, adult preference and relative larval performance were basically irrelevant for predicting ecological impact here. Once the weevils had dispersed into the region, the sparse less-preferred native thistles provided the only acceptable resource for the weevils. Interestingly, one inference from this result is that relative preference and performance could become irrelevant if biological control succeeds in reducing the density of its targeted host plant. As the preferred weedy species becomes less available, the acceptable secondary native species may become more vulnerable.
This study is the first quantitative re-evaluation of host specificity in a case with documented non-target feeding by a screened biological control agent for an exotic weed. The results suggest that the host-specificity criteria, adult preference and larval performance, only provided evidence that feeding could occur on the native Cirsium spp. The use of these criteria to predict relative impact on native species fell short of doing so for Platte thistle (C. canescens), the one case with quantitative data on seed production and regeneration before and after $R$. conicus adoption of a native thistle. Thus, the data from this case history now provide quantitative support for the suggestion that additional, ecological criteria are needed to estimate the potential ecological risk of biological control agents to native species that are secondary host plant species (Harris and McEvoy, 1985; McEvoy, 1996; Louda, 1998, 1999; Louda et al., 1998; Strong and Pemberton, 2000). We conclude that this case history provides a challenge to host specificity as a definitive criterion for predicting ecological effects, specifically when the standard tests indicate that the host range likely includes native species as secondary hosts (Pemberton, 2000).

Other insect species that have been released in contemporary biological control programs may have similar potential for unexpected side effects. For example, the purple loosestrife borer (Hylobius transversovittatus Goeze: Curculionidae) was introduced into North America in 1992 for the control of purple loosestrife (Lythrum salicaria L.). Host specificity tests provided evidence that this weevil would oviposit on native species (L. alatum Pursh., Gaura parviflora Dougl.) and that larval development was successful on some native species (L. alatum Pursh.; Docodon verticillatus (L.) Ell.; Blossey et al. 1994). Yet, as is usual, Blossey et al. (1994, p. 131) concluded: "Results of the host specificity screening demonstrated that [the natives] swamp loosestrife and winged lythrum ... should be safe from attack by the purple loosestrife borer." Based on our results and the other recent evidence on non-target use of native species (above), this conclusion appears premature. In cases such as this, we suggest further tests of population growth and impact on native species when the preferred (targeted) host species is rare appear merited. This suggestion is reinforced by the results of a recent review of non-target effects in weed biological control cases. Pemberton (2000) found that non-target effects are almost exclusively recorded in cases of biological control where the targeted weed has native relatives and when the alien insect agents are not strictly monophagous.

Additional ecological criteria, such as relative flowering phenology and relative availability of alternative acceptable species, could be used to supplement host specificity tests (Harris and McEvoy, 1985; Louda, 1998, 1999, 2000). In this case, phenological similarity 
in flowering between Platte thistle and Musk thistle, and their synchrony with $R$. conicus oviposition, suggest that Platte thistle should have been tested as a potential host (Louda, 1998, 1999, 2000; Louda and Arnett, 2000). In addition, ecological theory suggests that, when population densities of interacting species are spatially and temporally dynamic, prediction of interaction strength requires information on predator (herbivore) acceptance and performance on alternate prey (hosts) when the preferred prey species is rare or absent (no choice tests), as well as when the preferred species is available (choice tests). Although the utility and importance of no-choice tests in biological control has been questioned (e.g. Blossey, 1995; Clements and Cristofaro, 1995; Marohasy, 1998), this case provides quantitative data in support of the suggestion that such tests are likely to be important in the prediction of ecological risk (e.g. Harris and McEvoy, 1985; Strong and Pemberton, 2000).

The results presented here are important for the conservation community, we think, because they suggest that evaluation of environmental risk associated with the release of exotic insects in biocontrol introductions is still incomplete. In our case, host specificity was not adequate to predict the interaction in the field and its population consequences for a native plant that was acceptable to, but not preferred by, the biological control agent. Thus, we conclude that the scientific protocols used to assess such environmental risk could be improved. Ecological parameters that could provide some of the needed supplementary insights include data on: (i) life history of related, potential hosts (Louda et al., 1997, 1998); (ii) spatial and temporal variability of the targeted invasive plant and the native potential host plant (Diehl and McEvoy, 1989); (iii) density-dependence of an alien insect's response to native species in relation to exotics (Denno and Peterson, 1996); and (4) potential indirect effects on native communities mediated through food webs (Andres, 1985; McEvoy, 1996; Simberloff and Stiling, 1996; Stiling and Simberloff, 2000; Henneman and Memmott, 2001; Louda and Rand, 2001). Additional study of other biological control projects already in progress could be used to evaluate these suggestions.

\section{Acknowledgments}

We thank Rich Alward, Alex Basolo, Todd Campbell, Andre Gassmann, Tony Joern, Tamara Minnick, Dennis O'Dowd, Bob Pemberton, Tatyana Rand, Urs Schaffner, Dan Simberloff and Don Strong for discussions of this work; Abby Rogers Kula for help with the experiments; and, Cedar Point Biological Station staff for exceptional logistical support. This study was supported by NSF grant DEB 96-15299.

\section{References}

Andres, 1985 L. A. Andres, Interactions of Chrysolina quadrigemina and Hypericum spp. In: E. S Delfosse, Editor, California, Proceedings of the VI International Symposium on the Biological Control of Weeds, Agriculture, Canada, Ottawa (1985), pp. 235-239.

Blossey, 1995 B. Blossey, Host specificity screening of insect biological weed control agents as part of an environmental risk assessment. In: H. M. T. Hokkanen and J. M. Lynch, Editors, Biological Control: Benefits and Risks, Cambridge University Press, Cambridge, UK (1995), pp. 84-89.

Blossey et al., 1994 B. Blossey, D. Schroeder, S. D. Hight, and R. A. Malecki, Host specificity and environmental impact of the weevil Hylobius transversovittatus, a biological control agent of purple loosestrife (Lythrum salicaria). Weed Science 42 (1994), pp. 128-133.

Boettner et al., $2000 \triangleright$ G. H. Boettner, J. S. Elkinton, and C. J. Boettner, Effects of a biological control introduction on three nontarget native species of Saturniid moths. Conservation Biology 14 (2000), pp. 1798-1806.

Clement and Cristofaro, 1995 S. L. Clement and M. Cristofaro, Open-field tests in host-specificity determination of insects for biological control. Biocontrol Science and Technology 5 (1995), pp. 395-406.

Debach and Rosen, $1991 \longrightarrow$ P. Debach and D. Rosen, Biological Control by Natural Enemies, 2nd ed., Cambridge University Press, Cambridge (1991).

Denno and Peterson, 1996 R. F. Denno and M. A. Peterson, Density-dependent dispersal and its consequences for population dynamics. In: N. Cappuccino and P. W. Price, Editors, Population Dynamics: New Approaches and Synthesis, Academic Press, San Diego, CA (1996), pp. 113-130.

Delfosse, 2000 E. S. Delfosse, Biological control: important tool for managing invasive species. Agricultural Research 48 (2000), p. 2.

Diehl and McEvoy, 1989 J. W. Diehl and P. B. McEvoy, Impact of the Cinnabar Moth (Tyria jacobaeae) on Senecio triangularis, a non-target native plant in Oregon. In: E. S Delfosse, Editor, Proceedings of the VII International Symposium on Biological Control of Weeds, Instituto Sperimentale per la Patologia Vegetale Ministero dell'Agricoltura e delle Foreste, Rome (1989), pp. 119-126.

Follett and Duan, $2000-$ P. Follett and J. Duan, Editors, Nontarget effects of biological control, Kluwer Academic Publishers, Dordrecht (2000).

Goeden and Ricker, 1986a $>$ R. D. Goeden and D. W. Ricker, Phytophagous insect faunas of the two most common native Cirsium thistles, C. californicum and C. proteanum, in southern California. Annals of the Entomological Society of America 79 (1986), pp. 953-962.

Goeden and Ricker, 1986b $>$ R. D. Goeden and D. W. Ricker, Phytophagous insect faunas of two introduced Cirsium thistles, $C$. ochrocentrum and C. vulgare, in southern California. Annals of the Entomological Society of America 79 (1986), pp. 945-952.

Goeden and Rucker, 1987a $>$ R. D. Goeden and D. W. Ricker, Phytophagous insect faunas of native Cirsium thistles, $C$. mohavense, $C$. neomexicanum, and C. nidulum, in the Mojave Desert of southern California. Annals of the Entomological Society of America 80 (1987), pp. 161-175.

Goeden and Ricker, 1987b $>$ R. D. Goeden and D. W. Ricker, Phytophagous insect faunas of the native thistles, Cirsium brevistylum, Cirsium congdonii, Cirsium occidentale, and Cirsium tioganum in southern California. Annals of the Entomological Society of America 80 (1987), pp. 152-160.

Harris and McEvoy, 1985 P. Harris and P. McEvoy, 1985. The predictability of insect host plant utilization from feeding tests and suggested improvements for screening weed biological control agents. Proceedings of the VIII International Symposium on Biological Control of Weeds. CSIRO, Melbourne, pp. 125-131.

Henneman and Memmott, 2001 M. L. Henneman and J. Memmott, Infiltration of a Hawaiian community by introduced biological control agents. Science 293 (2001), pp. 1314-1316.

Herr, 2000 J. C. Herr, Evaluating non-target effects: the thistle story. In: M. S. Hoddle, Editor, Proceedings of the California Conference on 
Biological Control II, July 11-12, 2000, University of California, Riverside (2000), pp. 12-17.

Howarth, 1991 F. G. Howarth, Environmental impacts of classical biological control. Annual Review of Entomology 36 (1991), pp. 485-509.

Johnson and Stiling, 1998 D. M. Johnson and P. D. Stiling, Distribution and dispersal of Cactoblastis cactorum (Lepidoptera: Pyralidae), an exotic Opuntia-feeding moth, in Florida. Florida Entomologist 81 (1998), pp. 12-22.

Louda, 1998 S. M. Louda, Population growth of Rhinocyllus conicus (Coleoptera: Curculionidae) on two species of native thistles in prairie. Environmental Entomology 27 (1998), pp. 834-841.

Louda, 1999 S. M. Louda, Ecology of interactions needed in biological control practice and policy. Bulletin of the British Ecological Society 29 (1999), pp. 8-11.

Louda, $2000 \checkmark$ S. M. Louda, Negative ecological effects of the Musk thistle biocontrol agent, Rhinocyllus conicus Fröl. In: P. A Follett and J. J. Duan, Editors, Nontarget Effects of Biological Control, Kluwer Academic Publishers, Dordrecht (2000), pp. 215-243.

Louda and Arnett, 2000 S. M. Louda and A. E. Arnett. 2000. Predicting non-target ecological effects of biological control agents: Evidence from Rhinocyllus conicus. In N. R. Spencer, editor. Proceedings of the X International Symposium on Biological Control of Weeds. USDA, Agricultural Research Service, Sydney, MT, pp. 551-567.

Louda and O'Brien, 2001 S. M. Louda and C. W. O'Brien. 2001. Unexpected ecological effects of distributing the exotic weevil, Larinus planus (f. ), for the biological control of Canada thistle. Conservation Biology (in press).

Louda and Rand, 2001 S. M. Louda and T. A. Rand. 2001. Native thistles: expendable or integral to ecosystem resistance to invasion? In: P. Kareiva, S. Levin, and R. Paine, eds., The Importance of Species. Princeton University Press, Princeton.

Louda et al., 1997 S. M. Louda, D. Kendall, J. Connor, and D. Simberloff, Ecological effects of an insect introduced for the biological control of weeds. Science 277 (1997), pp. 1088-1090.

Louda et al., 1998 S. M. Louda, D. Simberloff, G. Boettner, J. Connor, D. Kendall, and A. E. Arnett, Insights from data on the nontarget effects of the flowerhead weevil. Biocontrol News and Information 19 (1998), pp. 70N-71N.

MacFadyen, 1998 R. E. MacFadyen, Biological control of weeds. Annual Review of Entomology 43 (1998), pp. 369-393.

Malecki and Blossey, 1994 R. Malecki and B. Blossey. 1994. Insect biological weed control: an important and underutilized management tool for maintaining native plant communities threatened by exotic plant introductions. In: Transactions, 59th North American Wildlife and Natural Resource Conference (1994). Wildlife Management Institute, Washington, DC, pp. 400-404.

Marohasy, 1998 J. Marohasy, The design and interpretation of host-specificity tests for weed biological control with particular reference to insect behavior. Biocontrol News E Information 19 (1998), pp. $13 \mathrm{~N}-20 \mathrm{~N}$.

McClay, 1990 A. S. McClay, The potential of Larinus planus (Coleoptera: Curculionidae), an accidentally-introduced insect in North America, for biological control of Cirsium arvense. In: E. S. Delfosse, Editor, Proceedings of the VII International Symposium on Biological Control of Weeds, 6-11 March 1988, Instituto Sperimentale per la Patologia Vegetale Ministero dell'Agricoltura e delle Foreste, Rome, Italy (1990), pp. 173-179.

McEvoy, 1996 P. B. McEvoy, Host specificity and biological pest control. BioScience 46 (1996), pp. 401-405.

Murdoch et al., $1985-$ W. W. Murdoch, J. Chesson, and P. L. Chesson, Biological control in theory and practice. American Naturalist 125 (1985), pp. 344-366.

Obrycki et al., 1998 J. J. Obrycki, K. L. Giles, and A. M. Ormord, Interactions between an introduced and indigenous coccinellid species at different prey densities. Oecologia 117 (1998), pp. 279-285.

Office of Technology Assessment, 1993 Office of Technology Assessment, US Congress, Harmful Non-Indigenous Species in the United States, OTA-F-565., US Government Printing Office, Washington, DC (1993).

Palmisano and Fox, 1997 S. Palmisano and L. R. Fox, Effects of mammal and insect herbivory on population dynamics of a native Cali- fornian thistle, Cirsium occidentale. Oecologia 111 (1997), pp. 413-421.

Pemberton, $2000-$ R. W. Pemberton, Predictable risk to native plants in weed biological control. Oecologia (Berlin) 125 (2000), pp. 489-494.

Pimentel et al., 2000 D. Pimentel, L. Lach, R. Zuniga, and D. Morrison, Environmental and economic costs of nonindigenous species in the United States. BioScience 50 (2000), pp. 53-64.

Randall, 1996 J. M. Randall, Weed control for the preservation of biological diversity. Weed Technology 10 (1996), pp. 370-383.

Rees, 1977 N. E. Rees, Impact of Rhinocyllus conicus on thistles in southwestern Montana. Environmental Entomology 6 (1977), pp. 839-842.

Rees, 1978 N. E. Rees, Interactions of Rhinocyllus conicus and thistles in the Gallatin Valley. In: K. E. Frick, ed., Biological Control of Thistles in the Genus Carduus in the United States: A Progress Report, Science and Education Administration, USDA, New Orleans, LA (1978), pp. 31-38.

Simberloff, 1986 D. Simberloff, Introduced insects: a biogeographic and systematic perspective. In: H. A. Mooney and J. A. Drake, Editors, Ecology of Biological Invasions of North America and Hawaii, Springer-Verlag, New York (1986), pp. 3-26.

Simberloff, 1992 D. Simberloff, Conservation of pristine habitats and unintended effects of biological control. In: W. C. Kauffman and J. E. Nechols, Editors, Selection Criteria and Ecological Consequences of Importing Natural Enemies, Entomological Society of America, Lantham, MD (1992), pp. 103-117.

Simberloff and Stiling, 1996 D. Simberloff and P. Stiling, How risky is biological control?. Ecology 777 (1996), pp. 1965-1974.

Stiling and Simberloff, $2000-$ P. Stiling and D. Simberloff, The frequency and strength of non-target effects of invertebrate biological control agents. In: P. Follett and J. J. Duan, Editors, Nontarget Effects of Biological Control, Kluwer Academic Publishers, Dordrecht (2000), pp. 31-43.

Strong and Pemberton, 2000 D. R. Strong and R. W. Pemberton, Biological control of invading species - risk and reform. Science 288 (2000), pp. 1969-1970.

Thomas and Willis, $1998 \rightarrow$ M. B. Thomas and A. J. Willis, Biocontrol - risky but necessary?. Trends in Ecology and Evolution 13 (1998), pp. 325-329.

Turner et al., 1987 C. E. Turner, R. W. Pemberton, and S. S. Rosenthal, Host utilization of native Cirsium thistles (Asteraceae) by the introduced weevil Rhinocyllus conicus (Coleoptera: Curculionidae) in California. Environmental Entomology 16 (1987), pp. 111-115.

USDA, Natural Resource Conservation Service, 1999 USDA, Natural Resource Conservation Service. 1999. The PLANTS database. National Plant Data Center, Baton Rouge, LA. Online at http:// plants. usda. gov/plants/ (accessed November 12, 2000).

Van Driesche and Bellows, $1993 \rightarrow$ R. G. Van Driesche and T. S. J. Bellows, eds., Steps in classical arthropod biological control, Entomological Society of America, Lantham, MD (1993).

Wajnberg et al., 2001 E. Wajnberg, J. K. Scott, and P. C. Quimby, eds., Evaluating indirect ecological effects of biological control, CABI Publishing, Wallingford, Oxon, UK (2001).

Wilcove et al., 1998 D. S. Wilcove, D. Rothstein, J. Dubow, A. Phillips, and E. Losos, Quantifying threats to imperiled species in the United States. BioScience 48 (1998), pp. 607-615.

Zwölfer, 1964 H. Zwölfer, Weed Projects for Canada. Progress Report No. X: Larinus and Rhinocyllus, Report Edition. Commonwealth Institute of Biological Control, European Station, Delemont, Switzerland (1964).

Zwölfer, 1967 H. Zwölfer. 1967. The host-range, distribution, and life-history of Rhinocyllus conicus Froel. (Col., Curculionidae). Weed projects for Canada, Progress Report No. XVIII. Commonwealth Institute of Biological Control, European Station, Delemont, Switzerland.

Zwölfer, 1969 H. Zwölfer. 1969. Additional feeding and oviposition tests with Rhinocyllus conicus Froel. Weed Projects for Canada, Progress Report No. XXIV. Commonwealth Institute of Biological Control, European Station, Delemont, Switzerland.

Zwölfer and Harris, $1984 \longrightarrow \mathrm{H}$. Zwölfer and P. Harris, Biology and host specificity of Rhinocyllus conicus (Fröl. ) (Col., Curculionidae), a successful agent for biocontrol of the thistle, Carduus nutans L. Zeitschrift der Angewandte Entomologie 97 (1984), pp. 36-62. 